\title{
БЕЗСПОЛУЧНИКОВЕ СКЛАДНЕ РЕЧЕННЯ В ОБРАЗНОМУ КОНТУРІ УКРАЇНСЬКОЇ НАРОДНОЇ ЗАГАДКИ
}

Онищенко Г. А. Безсполучникове складне речення в образному контурі української народної загадки.

У статті досліджено українську загадку як своєрідний вид народної творчості, який через вербалізовані національно-культурні стереотипи відображає етнічне «Я» українців. У структурі загадки виокремлено дві частини - образну (описову) і відповідь. Акцентовано на тому, що найчисленнішим серед усіх різновидів складних речень в образній частині загадки $є$ тип конструкцій із безсполучниковим зв'язком. Вони представлені всіма структурними різновидами, серед яких найчастотнішими є структури із зіставним значенням.

Ключові слова: фольклор, усна народна творчість, українська народна загадка, безсполучникове складне речення, образна частина загадки.

Онищенко Г. А. Беспредложное сложное предложение в образном контуре украинской народной загадки.

В статье исследуется украинская народная загадка как своеобразный вид народного творчества, который через вербализированные национальнокультурные стереотипы отражает этническое «Я» украинцев. В структуре загадки выделяются две части - образная (описательная) и ответ. Акцентируется внимание на том, что самым многочисленным среди всех разновидностей сложных предложений в образной части загадки является тип конструкций с беспредложной связью. Они представлены всеми структурными разновидностями, среди которых чаще всего обнаруживаются структуры с сопоставительным значением.

Ключевые слова: фольклор, устное народное творчество, украинская народная загадка, беспредложное сложное предложение, образная часть загадки.

Onyshchenko G. A. Asyndetic compound sentence in the Ukrainian folk riddle imagery.

The article studies the Ukrainian riddle as a unique type of folk art that by means of verbalized national and cultural stereotypes reflects the ethnic singularity of the Ukrainians, their world perception and its rendering in the form words, word combinations and set phrases. The Ukrainian folk riddle is an element of the cultural code of the Ukrainian speaking personality and a source of oxpression of language 
peculiarities of the Ukrainian literary speech. The Ukrainian folk riddle is a linguocultural mini text that is considered to be an important language unit for studying the relations between the language and the culture, the language and the poetic way of thinking of people. The texts of the Ukrainian riddles have always been the subject of researches in such field as folklore studies, linguistics, linguostylistics, stylistics, cultural studies and rhetoric. The peculiarity of the riddle as a singular folklore genre is concentrated on a certain subject, in particular, on the selection of the riddle object, denotation to which the mini text is dedicated. Moreover, its peculiar feature is based on laconism, compression of the expressed thought, content paradoxicality and clear syntactical form of the text.

Studying a riddle as a literary element of oral tradition, as an individual genre that was created within the history, the researchers have determined two main elements in the structure of the riddle: figurative, descriptive (expressed by the speaker) and the answer (of the listener) that is the solution of the riddle. Nevertheless, the first element is considered more attractive for making linguistic researches. It is known that asyndetic sentences are quite popular in the modern speech. On the one hand, the classifications of these sentences are based on the sense relations between the elements (the asyndetic sentences correspond to the conjunctive ones), on the other hand, they are based on the intonation peculiarities of the sentences of each type. The main attention is paid to the fact that the constructions with asyndetic relations in the figurative element of the riddle are mostly observed in the compound sentences.

They are represented by all the structural types and among them the combinations that have comparative meaning are mostly widespread. As a general matter, the comparison of the parallel syntactical constructions that have contrary content create the riddles with contradictory meaning which are considered riddles of paradoxical type. In the asyndetic sentences which have enumerating and comparative meanings we can seldom observe free word order because of the rules and norms of rhythmical system of the language and lexical composition of the figurative part of the riddle. It has been concluded that there is rather a small number of riddles created due to the asyndetic sentence patterns with semantic relations expressing conditions and explanations.

Key words: folklore, oral tradition, the Ukrainian folk riddle, asyndetic compound sentence, figurative element of the riddle.

Українська народна загадка, як відомо, належить до зразків лінгвокультурного мікротексту і є важливим джерелом вивчення зв'язку мови і культури, мови й поетичного мислення народу. Специфіка загадки як самостійного фольклорного жанру полягає, власне, у виборі загадуваного об'єкта, денотата, якому присвячено 
мікротекст, у лаконізмі, сконденсованості висловленої думки, парадоксальності змісту, чіткій синтаксичній формі.

Першою спробою дослідження цього фольклорного жанру можна вважати працю I. Франка «Останки первісного світогляду в руських і польських загадках народних». Українській загадці присвячено наукові студії О. Афанасьєва, І. Березовського, Л. Дунаєвської, Ф. Лаврова, В. Перетца, М. Попова, О. Потебні, К. Сементовського, М. Сумцова, М. Хмелюка та ін.

Тексти українських загадок були предметом дослідження лінгвостилістики, культурології, риторики тощо (праці В. Анікіна, О. Берегової, Е. Кенгс-Маранди, Н. Мечковської, А. Мойсієнка, Г. Пасько, О. Селіваново, Н. Сивачук та ін.). У слов'янському мовознавстві загадка вивчалася 3 погляду семіотики (А. Головачова, А. Журинський, Ю. Левін).

Мова загадок через вербалізовані національно-культурні стереотипи відображає етнічне «Я» українців, їхнє сприймання зовнішнього світу і його відтворення у слові, словосполученні, сталому звороті. Як справедливо зауважує В. Жайворонок, «Мова $<$...> відбиває етнокультурні стереотипи, породжені національною специфікою людського світосприймання» [3, с. 27]. Українська народна загадка $€$ елементом культурного коду україномовної особистості, виразником мовних особливостей українського літературного мовлення [14, с. 162].

Розглядаючи загадку як художній твір усної народної творчості, як самостійний жанр, що склався історично, дослідники виділяють дві частини у структурі загадки - образну, описову (вимовляється адресантом) і відповідь (адресата), тобто розгадку. Проте головну увагу зосереджують на першій частині: «Загадка метафоричний вислів, хитромудре питання, розраховане на догадливість, кмітливість тих, що розгадують» [8, с. 225]. Пор.: «Загадка вживається не лише для активації пізнавальних можливостей дитини, практикованої етнопедагогікою, чи гуртової розваги, а й почасти містить у собі філософський зміст,

С Г. А. Онищенко, 2018. 
пов'язується із міфологічним світобаченням» [6, с. 276]. Щодо механізму розшифрування денотата загадки за допомогою відбору інформації про нього і «перероблення» на цій основі змістового плану тексту, О. Селіванова виокремлює «концептуальну фільтрацію», результатом якої є відгадка. Саме у процесі цієї фільтрації відбувається перероблення i розподіл таких взаємопов'язаних програм дискурсу, як шифрування та підказка [10, с. 257].

Найчисленнішим серед усіх різновидів складних речень в образній частині загадки $є$ тип конструкцій із безсполучниковим зв'язком. Як відомо, безсполучникові речення досить поширені в усному мовленні. Класифікації цих речень, 3 одного боку, грунтуються на врахуванні смислових відношень між частинами (безсполучникові речення співвідносяться зі сполучниковими), з іншого, - на врахуванні інтонаційних особливостей речень кожного типу.

У загадці представлені речення, у яких перераховуються явища, події, пов'язані між собою в часі. Названі речення можуть складатися 3 двох, трьох, чотирьох, п'яти, шести, семи та навіть восьми предикативних частин, наприклад: 1) Постелю кожушок, висиплю горошок (відгадка: Небо $і$ зорі) [14]; 2) Летіла тетеря не вчора - тепера, впала в лободу, шукаю не найду (відгадка: Зоря) [4]; 3) Над бабиною хатою стоїть байда хліба, собаки гавкають, не можуть дістати (відгадка: місяиь) [14]; 4) Стоїть дуб-вертодуб, на тім дубі-вертолубі сидить птиця-вертолиия, ніхто ї̈ не дістане, ні иар, ні иариџя, ні красна дівиця, ні попи, ні дяки, ні ми, дураки (відгадка: небо і сонце) [4]; 5) Зимою біле, весною чорне, літом зелене, осінню стрижене (відгадка: поле) [4]; 6) Їхала пані на барабані, загубила ключі на майдані; місяиь ішов, ключі не найшов; сонце йшло, ключі найшло (відгадка: роса [4]; 7) Поїду в ліс, вирублю теліш; із того теліша ізроблю два човни, два столи, иило і покришку (відгадка: жолудь) [14]; 8) Живе у хаті звірьок: шуба в нього атласна, лапки бархатні, 
вушки малі та чуткі, очі горять як вугольки (відгадка: кіт) [14]; 9) Стоїть дуб, на дубі гай, під гаєм моргай, під моргаєм кліпун, nід кліпуном двигун, під двигуном сопун, під сопуном хапун, під хапуном трясун (відгадка: людина) [4]; 10) Був собі гай, за гаєм моргай, за моргаєм глядай, за хапаєм тримай, за тримаєм бовтай, за бовтаєм ковтай (відгадка: волосся, брови, очі, ніс, зуби, язик, горло) [14]. У конструкціях з перелічувальною інтонацією поряд 3 однотипними частинами загадка досить активно використовує різнотипні (див. 1-й і 3-й приклади); у загадках-оповідях цієї групи помітні судження різного часового плану (див. 5-й приклад).

Дослідники зазначають, що більшість загадок побудована на граматичному паралелізмі, однорідності функцій, але на семантичних відмінностях. Принцип алогізму, за яким часто будується загадка, рельєфніше виявляється в зіставних конструкціях складного безсполучникового речення: Посягнеш досягнеш, оглянешся - i не увидиш (відгадка: вухо) [4]; Два брати під їдни дахом, їден другого не бачить (відгадка: очі) [4]; Фіртка без брами, вікна без иибок (відгадка: рот, очі) [4]; Без кореня $і$ без квіту - служить иілому світу (відгадка: сіль) [4]; Вище коліна, нижче пупа, всяк чоловік частенько щупа (відгадка: кишеня) [4].

Інколи загадки мають тотожну будову частин, але логічний розрив між частинами в одній із них робить речення зіставним. Наприклад: П'ять хлопчиків - n'ять хаток (відгадка: рукавичка) [4] і П'ять комірок, одні двері (відгадка: рукавичка) [4].

Синтаксичний паралелізм - це один із основних способів створення художнього образу в загадці. Проте формально однотипні компоненти безсполучникового складного речення передають семантичні відношення наслідковості, умовності, заперечності (протилежності), наприклад: Без рук, без ног - за сто верстов зайде (відгадка: листи [4]; Живе без тіла, говорить без язика (відгадка: книжка) [4]; Крикнула утка - на все село чутка (відгадка: дзвін) [4]; Hi вікон, ні дверей, повна хата людей 
(відгадка: гарбуз) [14].

Безсполучникові складні речення в образній частині загадок можуть компонуватися із елементів, які передають різне значення $\mathrm{i}$ формуються як перелічувально-зіставні конструкції: Чотири качається, два біжить, один сидить (відгадка: колеса, коні, віз) [4]; Сім братів віком рівні; іменами різні (відгадка: тиждень, дні тижня) [14]; В книжчі шість листків простих, сьомий золотий (відгадка: дні тижня) [4]; Сидить три коти, проти кожного кота сидить два коти, скільки всього котів? (відгадка: три) [4].

У наведених прикладах порядок частин чітко визначений: спочатку йде перелік, а останнє судження протиставляється іншим. Загадкам притаманні також паралельні зіставні конструкції, поєднані між собою за допомогою переліку, наприклад: Їду - їду - нема сліду, ріжу - ріжу - не наріжу (відгадка: човен) [4]; Летить - мовчить, торкни - дзижчить, візьми в руки - скиглить (відгадка: скрипка) [14].

Синонімічність безсполучникових складних речень 3 перелічувальною та зіставною інтонацією та сполучникових складносурядних речень репрезентується досліджуваними загадками. Пор.: 1) Тичечка, на тій тичечиі капличка, у тій капличияі сорок паничів (відгадка: мак) [14] і Стоїть тичка, а на той тичці табличка, а в той табличці сорок сороків (відгадка: мак) [14]; 2) Шкіру носимо, м'ясо бросимо, голову з '̈̈мо (відгадка: коноплі) [14] і Тіло викидають, шкіру носять, а голову їять (відгадка: коноплі) [14].

Розглянуті безсполучникові конструкції рідко допускають вільний порядок розташування частин: цьому чинять перешкоди закони ритміки, а також лексичне наповнення. Наприклад: Били мене, колотили мене, во всі чини призводили, на престол з царем посадили (відгадка: льон) [4]; Не гни мене, не ломни мене; злізь на мене та натьопайся (відгадка: вишня) [14]; Весною біле, літом зелене, восени жовте, взимку добре (відгадка: груша) [4]; Молодий кінь за морем бував, спереді иильце, ззаді вильце, на грудях біле 
полотенце (відгадка: ластівка) [14]; В темній хатині живуть Мартини, в'яжуть кружева без петлі й узла (відгадка: бджоли у вулику) [14]; Стоять вила, на вилах барило, на барилі цуокотуха, на цокотусі лепетуха, над лепетухою гора, на горі комен (відгадка: людина) [14]. Переставляння частин у реченнях призводить до порушення послідовності подій або порядку опису предметів. У першому прикладі при перенесенні останньої частини на друге місце зберігається структура речення, але відбувається зміна ритмічного малюнка загадки, порушується логічна послідовність змісту. Пор.: Били мене, на престол з царем посадили, колотили мене, во всі чини призводили [4].

Малочисельну групу загадок утворюють тексти, образна частина яких побудована за моделлю безсполучникового складного речення з вираженими відношеннями умови, наприклад: 1) Тільки сонще припече, воно зразу оживе (відгадка: бджола) [4] умовне значення; 2) Прийшли мужики без сокир, збудували дім без кутів (відгадка: мурашки) [14] - умовно-наслідкове значення; 3) Трави вхоплю - зуби натоплю; піску вхватю - знову нагострю (відгадка: коса) [4] - умовно-часове значення.

Частини безсполучникового складного речення зі значенням умови входять до складу багаточлена, з'єднаного посередництвом зіставної чи перелічувальної інтонації, наприклад: Летіла тетеря не вчора - тепера, впала в лободу, шукаю - не найду (відгадка: зоря) [4]; Їхав по горі волох, розсипав горох; стало світати - нема щзо збирати (відгадка: місяц̧ь $i$ зорі) [14] - частини з умовним значенням з'єднані способом перелічування. Здебільшого відношення між двочленами або одночленом і двочленом мають зіставний, частіше протиставний характер, наприклад: Вперед ішла - ключі найшла; місяць уздрів, сонще вкрало (відгадка: роса) [4]; Летить - виє, сяде - риє (відгадка: жук) [14]; В лісі жило - мохом обросло, прийшло до хати - стало співати (відгадка: сопілка) [4].

Безсполучникових пояснювальних речень також небагато. Серед них переважають структури, у яких друга частина виконує

(С Г. А. Онищенко, 2018. 
функцію означально-пояснювального характеру, наприклад: Шийка тоненька, ззаді западенька (відгадка: пляшка) [4]; Дуб-ясен весь перепоясан; збоку дірка, ззаді шпилька (відгадка: діжка) [4]; Перед двора стоїть копиия, спереду вила, ззаду мітла (відгадка: корова) [14]; Іде пані красна, на їй ризка рясна, між ногами смашна (відгадка: вівия) [4]. Інколи слово, яке пояснюється наступною частиною (частинами), буває відділене іншими членами, що надає означальній частині певної самостійності й наближає до перелічувальних чи зіставних конструкцій: Сто коней не повезе, кільки він на собі несе (відгадка: пароплав) [4]; Нама доня дерев'яна, в неї спина солом'яна (відгадка: жлукто) [4].

Загадки-описи об’єднують в одну синтаксичну конструкцію предикативні частини, що репрезентують різний граматичний час: 1) Шило-вило мотовило попід небо заходило, по-німецьки говорило, по-турецьки заводило (відгадка: ластівка) [14] та Спереду шильще, а ззаду вильце; ззаду суконще, а спереду біле полотенце (відгадка: ластівка) [4]; 2) Молодий кінь за морем бував, спереді иильце, ззаді вильще, на грудях біле полотенце (відгадка: ластівка) [14] та Маленький котик за морем буває, спереді шильие, ззаду вильце, на руках біла хусточка (відгадка: ластівка) [14]. Інші структурні типи пояснювальних речень рідковживані. Наприклад: До чого народ доходить, самовар по річиі ходить (відгадка: пароплав) [4] - друга частина має пояснювальне значення.

Отже, безсполучникові складні речення - найпоширеніший конструктивний тип в образній частині загадки. Вони представлені всіма структурними різновидами, серед яких найчастотнішими виявилися структури із зіставним значенням. Здебільшого на зіставленні паралельних синтаксичних конструкцій з протилежним змістом будуються загадки-парадокси. Безсполучникові речення з перелічувальним i зіставним значенням рідко дозволяють вільний порядок частин, бо цьому перешкоджають закони ритміки, а також лексичне наповнення образної частини загадки. Значно 
менше загадок побудовано за зразком безсполучникових речень із семантичними відношеннями умови та пояснення.

\section{Література}

1. Берегова О. А. Аранжування загадки питальним реченням / О. А. Берегова / Матеріали Міжнар. наук.-практ. конф. наук. робіт молодих учених / відп. ред. О. В. Семенова. - Горлівка : Вид-во ГПДІІМ, 2011. - С. 23.

2. Берегова О. А. Загадка крізь призму сучасного мовознавства / О. А. Берегова // Молодий вчений. - 2016. - № 3(30). - С. 519-522.

3. Жайворонок В. Українська етнолінгвістика: деякі аспекти досліджень / В. Жайворонок // Мовознавство. - 2004. - № 5 - С. 48-63.

4. Загадки / Упоряд. І. П. Березовський. - К. : Вид-во АН УРСР, 1962. - 510 с.

5. Кенгс-Маранда Э. Логика загадки / Э. Кенгс-Маранда // Пословица. Загадка (структура, смысл, тип). - 1978. - С. 249-284.

6. Літературознавчий словник-довідник / Р. Т. Гром'як, Ю. І. Ковалів та ін. К. : ВЦ «Академія»,1997 - 752 с.

7. Мойсієнко А. К. Народна загадка в текстово-дискурсивному вимірі / А. К. Мойсієнко // Українська мова. - 2013. - № 3. - С. 39-47.

8. Пазяк М. М. Загадка / М. М. Пазяк // Українська літературна енциклопедія. - К. : Головна ред. УРЕ ім. І. П. Бажана, 1990. - С. 225.

9. Пасько Г. М. Особливості вияву комунікативної мети мовленнєвого жанру загадки в аспекті класичної теорії мовленнєвих актів (на матеріалі української мови) / Г. М. Пасько // Донецький вісник Наук. тов.-ства. ім. Шевченка / гол. ред. В. Білецький. - 2010. - Т. 28. - С. 273-282.

10. Селиванова Е. А. Когнитивные механизмы денотации украинской загадки / Е.А. Селиванова // Ученые записки Таврического национального ун-та им. В. И. Вернадского. Филология. - Т. 18 [57]. - № 2. - Симферополь, 2005. C. $256-261$.

11. Селіванова О. О. Комунікативні стратегії і тактики в українських загадках / О. О. Селіванова // Вісник Черкаського ун-ту. - Серія : Філологічні науки. 2004. - Вип. 60. - С. 10-23.

12. Сивачук Н. Загадка як фольклорний жанр / Н. Сивачук // Рідна мова. 2003. - № 4. - C. 25-28.

13. Степанова Т. Використання загадок у розвитку виразності мовлення майбутніх вихователів дошкільних навчальних закладів / Т. Степанова // Психолого-педагогічні проблеми сільської школи. - Вип. 52. - 2015. - С. 160-165.

14. Українські народні загадки / Упоряд. М. Шестопал. - К. : Вид-во АН УРCP, 1963. $-399 \mathrm{c}$.

Стаття надійшла до редакиії 08.11.2017 p.

(ㄷ Г. А. Онищенко, 2018. 